\title{
Faculty Perceptions of Cleanliness and Safety on a College Campus During the COVID-19 Pandemic
}

\author{
Mary E. Ogidigben \\ Kennesaw State University \\ Ernesto R. Rivera \\ Kennesaw State University \\ Robert S. Keyser \\ Kennesaw State University
}

The coronavirus (COVID-19) pandemic has affected many institutions - one of which is Kennesaw State University (KSU). In the Fall 2020 semester, KSU implemented safety protocols following the Centers for Disease Control and Prevention (CDC) as well as the University System of Georgia (USG) guidelines. A cross-sectional survey was disseminated for faculty to complete at their own will regarding their thoughts on how the new guidelines are affecting their work as well as their safety while on campus. The survey consisted of 18 Likert-scale questions and eight free-response questions. The survey results showed that $60.42 \%$ of faculty members reported that they were trained regarding their new work requirements and that while faculty generally felt safe, they had concerns about specific areas on campus. As most classes across the KSU campus were forced to become fully online classes, faculty reported that their relationships with students changed as their class modalities changed. KSU faculty and students alike tried their best to adjust to the new environment and will continue to do so to promote safety and stop the spread of COVID19.

Keywords: COVID-19, pandemic, descriptive research, survey, Kennesaw State University, cleanliness, safety

\section{INTRODUCTION}

Reports of the COVID-19 coronavirus first surfaced in December 2019 (Borowiak, et al., 2020), but gained worldwide attention in January 2020 when the World Health Organization (WHO director-general's opening remarks at the media briefing on COVID-19 - 11 March 2020, 2020) declared the COVID-19 outbreak a "public health emergency of international concern" (Kennedy, 2020). In February 2020, the Centers for Disease Control (CDC) provided guidelines on how to protect yourself and others. These guidelines included wearing a mask, maintaining a 6-foot distance from others, avoiding crowds, washing hands, covering coughs and sneezes, disinfecting frequently touched surfaces, and monitoring daily health (Coronavirus disease 2019 (COVID-19), 2019). On March 11, 2020, the Director General of the World 
Health Organization characterized COVID-19 as a pandemic in his opening remarks at a media briefing (WHO director-general's opening remarks at the media briefing on COVID-19 - 11 March 2020, 2020).

COVID-19 has had a profound impact on the world at large, including college and university campuses during the Spring 2020 semester, over the summer, and leading to the Fall 2020 semester, the beginning of a new academic year. With new coronavirus cases ramping up over the summer months, many questioned why colleges and universities wanted students to return to campus in the Fall. Many schools took the position that Northeastern University assumed - principally, that students wanted to return to campus and their parents wanted them on campus, too (Auon, 2020). Conversely, institutions of higher learning face enormous financial pressures to bring students back on campus (Nocera, 2020). However, the return to campus did not come without many inherent risks. For example, many faculty members across the U.S. expressed grave doubts regarding their institutions' ability to safely bring students and staff together (Marek, 2020).

Many universities, such as the University of Alabama, the University of Southern California, The Ohio State University, and universities in Britain (1,000+ Colleges and universities sign-up for \#CampusClear, a free self-screening mobile app built by Ivy.ai) rolled back campus reopening plans due to COVID-19 outbreaks. Some universities, such as the University of North Carolina - Chapel Hill, Notre Dame University, and Michigan State University allowed students to move back on campus and then immediately asked students to leave campus due to a COVID-19 outbreak (Raimonde, 2020); (College road trip: UNC students move out after COVID-19 outbreak, 2020); (Camera, 2020); (Grayer \& Stuart, 2020). Examples of outbreak countermeasures implemented by universities included asking students and faculty to selfquarantine (Diep, 2020), providing mobile phone apps that allows users who test positive for COVID-19 to upload a magic key to alert other people which pings were dangerous and which ones were not (College road trip: UNC students move out after COVID-19 outbreak, 2020), and moving all face-to-face lectures to fully online lectures for the coming academic year (Vaghela, 2020). Many universities view testing students for the COVID-19 as the only safe way to bring students back on campus (Court \& Lorin, J., 2020). While several schools have provided COVID-19 guidelines for a safe return to campus, the concern that some schools may not follow the plan is prevalent (College athletes return to campus for voluntary training despite safety concerns, 2020).

Despite such countermeasures, there has been an increase in new coronavirus cases at institutions around the world. For example, although the University of Illinois conducted a mass testing for COVID19 , hundreds of asymptomatic cases have surfaced, mostly among undergraduate students (Nadworny \& Inskeep, S., 2020). Virus clusters have appeared at universities in France (Corbet \& Siegel, T., 2020). Fall coronavirus outbreaks have been linked to student fraternities and sororities (Reilly, 2020).

Issues that have surfaced on college campuses during the COVID-19 pandemic include modifying facilities such as libraries (Dixon, 2020), addressing the needs of college students with special needs (Gould, 2020), and managing the mental health of students (Aufderheide \& Gondles, E., 2020). Additional COVID-19 issues include athletes (Roetert, Bell, L., \& Hainline, B., 2020), people in general (Shuja, Aqeel, M., Jaffar, A., \& Ahmed, A., 2020), protecting the safety and well-being of the student LGBTQ+ community (Wood, 2020); (Weissman, 2020), and the effects and added responsibilities absorbed by the faculty (Alexander, 2020).

The coronavirus (COVID-19) pandemic has come with an abundance of uncertainty, including whether students should be allowed to return to college campuses. The University System of Georgia (USG) determined that if Georgia schools followed the safety guidelines set forth by the Centers for Disease Control and Prevention (CDC), students should be given the opportunity to return to campus for the 2020 Fall semester. As a part of the USG, Kennesaw State University made the decision to allow students to return to campus while working with faculty members to determine the safest way to deliver classes. This resulted in most professors delivering online and hybrid (50\% online, 50\% in-person) classes with very few traditional in-person classes. This descriptive study will use a survey to provide insight as to how faculty members have responded to changes in the classroom for safety during COVID-19 and will explore faculty perspectives on KSU's new policies concerning COVID-19. 
This study will focus on faculty perspectives as they adjust to their new classroom modality. The following research questions (RQ) will be explored:

RQ1: Were faculty members able to implement the safety guidelines put in place by Kennesaw State University?

RQ2: How did faculty members respond to their new environment?

RQ3: How did the changes to the school environment impact faculty members' classroom modalities and their relationships with students?

\section{LITERATURE REVIEW}

In response to the COVID-19 pandemic, plans to protect students, faculty, and staff from the virus resulted in several schools making the decision to deliver classes online. This online transition came with a lot of uncertainties as to how students and faculty would respond to such a big change. A main concern was how faculty and students would adjust to the new class modality.

(Mouchantaf, 2020) concluded that most faculty members were able to transition well and mostly mentioned "students missing lectures, technical complications, and a lack of institutional help and training" as areas that could improve. A medical college in North India also found that teachers were satisfied but contrary to (Mouchantaf, 2020), the students at the medical college reported feeling engaged and excited to learn (Khan, Patra, Vaney, Mehndiratta, \& Chauhan, R., 2021).

Technological competence among faculty members would certainly contribute to student engagement (König, Jager-Biela, \& Glutsch, N., 2020). While a lot of classes are taught online at Kennesaw State University (KSU), most of the classes are usually taught in-person. If faculty members do not feel comfortable maneuvering the technology necessary to teach online courses, then they may not be able to effectively communicate with their students, leaving their students feeling unengaged. This may be overcome by allowing a safe space for faculty to ask questions and address their concerns with online learning as suggested by (Justis, Litts, Reina, \& Rhodes, L., 2020).

\section{METHODOLOGY}

This section discusses the participants, materials, and procedures used in this study.

\section{Participants}

The participants in this study consisted of faculty members and staff at Kennesaw State University (KSU). Faculty members at KSU have a wide demographic in both age and race. While every faculty member registered with KSU was given a chance to complete the survey, only 48 responses were recorded. A total of 52 faculty members began the survey, but four members did not complete the survey questions beyond the online survey consent questions.

\section{Materials}

We deliberated over potential questions to generate survey questions that would directly answer the research questions that were driving the study. Once satisfied with the question pool, the IRB application and survey was submitted to and approved by the Institutional Review Board at Kennesaw State University. The survey consisted of eight free response questions and 18 Likert scale questions where:

$$
\begin{array}{ll}
1=\text { Strongly Agree } & 4=\text { Somewhat Disagree } \\
2=\text { Somewhat Agree } & 5=\text { Disagree } \\
3=\text { Neutral } & 6=\text { Strongly Disagree }
\end{array}
$$

All questions were directed towards faculty members and were focused on subjects that pertained to classroom modality, COVID-19 safety, and challenges faced in their new environment. 


\section{Procedures}

The data collection method was an online survey that was created using Qualtrics XM and then posted in the Kennesaw State University's online system for posting announcements, KSU Today, so faculty members and staff could complete it at their own will. At the end of the survey period, Qualtrics XM generated a report with the 52 responses that were received. Only 48 responses were useful as four of them had no data beyond the online survey consent questions.

To interpret the responses, descriptive statistics generated by Qualtrics XM were used to analyze the answers to the Likert-scale questions while the answers to the free-response questions were grouped by similar answers and served to provide more detailed responses for the researchers.

The Likert-scale questions were used in the Results section to quantify the research questions set forth above, while the free-response answers were used to provide quotes as additional proof of the conclusions drawn by the researchers.

\section{RESEARCH FINDINGS}

At the end of the ten-day survey period, Qualtrics XM provided the survey responses to all questions as well as descriptive statistics for the Likert-scale questions. Considering both the Likert-scale questions and the free-response questions, a full view of faculty members' thoughts and perceptions of safety, the new school environment, classroom modality, and faculty relationships with students were collected. These questions and responses were categorized into three sections that served as research questions RQ1, RQ2, and RQ3.

RQ1: Were faculty members able to implement the safety guidelines put in place by Kennesaw State University?

Based on the survey results in Table $3,60.42 \%$ of faculty members reported that they were trained regarding their new work requirements, $85.42 \%$ of faculty reported they were made aware of the Presidential Task Force, and $90 \%$ of those who responded to the survey were administered a KSU face mask and were made aware of the requirement to wear the masks. While most faculty members have not taken advantage of the on-campus COVID-19 testing, about half of the faculty have taken the COVID-19 Self-Assessment quiz provided by KSU. Based on free-response questions \#7 and \#8, three out of eight faculty members reported that they were provided with cleaning supplies and seven out of eleven faculty members reported using them regularly as well as reported that there were cleaning supplies in the classrooms. However, there were two responses stating that no cleaning supplies had been provided as well as the following response:

"I see cleaning supplies around the building. I also see someone come into my office which only I use and clean the door handle to a closet that has not been used in years every single day. Why? Seems like a waste of resources." (response to free response questions \#8)

This suggests that while each faculty member may not have been provided cleaning supplies, the custodial staff still made the effort to clean each office and classroom.

\section{RQ2: How did faculty members respond to their new environment?}

Based on the survey results in Table 5,70.83\% of faculty members reported that they felt comfortable and safe on campus overall, but when asked about specific places on campus, the results varied greatly. Due to differing results/comments when presented with sanitation effort questions in the survey, the results are inconclusive as to whether faculty are satisfied with the new cleaning/disinfecting efforts. Two responses from free-response question \#6 also revealed concerns over students and faculty alike who do not follow the guidelines, as well as the lack of required testing. One faculty member reported being "scared 
of colleagues who appear to forget their mask or don't want to wear it and don't seem to believe they should while wanting to speak with [them] in a single office setting." This faculty member continued saying, "I have felt 'hostage' to two different (male) colleagues who didn't think they needed to have a mask on for one-on-one interaction." It is not just faculty who are not following CDC guidelines. Another faculty member stated that they have "stress and anxiety of worrying that [they are] in an unsafe environment because students are not being careful." While these two responses and two more like it point to a fear of being on campus, the Likert-scale questions must also be taken into consideration. Looking at all the evidence, while faculty are unsure about their safety in some areas, $70.83 \%$ are somewhat confident about being on campus.

RQ3: How did the changes to the school environment impact faculty members' classroom modalities and their relationships with students?

From the Likert-scale survey questions in Table 7, 89.59\% of faculty members reported that COVID19 impacted the way they do work at KSU. One major difference shown in free-response questions \#1 and \#2 was that the staff held office hours almost exclusively online rather than in-person, and while more students attended the office hours, faculty found it difficult to connect with students both on- and offcampus. For on-campus meetings, one faculty member reported "indoor air quality and not wanting to be in close quarters" as a challenge of interacting with students on campus. This concurred with another response stating "students gather outdoors with no distance at all thus contributing to increase virus spread [and] also when indoors, in general people do not wear face masks properly not covering their noses" as a reason why face-to-face interaction was difficult.

Another major difference shown in free-response questions \#3-5 was classroom modality and attendance. While not all classes had to change their class format in response to COVID-19, some face-toface and hybrid classes were forced to go fully online. Because of this switch in class modalities, faculty had to adjust their class content to accommodate for demonstrations that would have required student involvement and class exercises that would be difficult to monitor online. For those classes that remained on campus, one of the faculty members reported 50\% less enrollment and another reported using rotational schedules to determine which students would be in class each day.

\section{DISCUSSION}

The results related to safety on campus were inconclusive. In contradiction with our initial thoughts, while faculty members claim to feel safe enough to be on campus, it appears that not all faculty members feel that enough safety precautions were taken. However, this is not uncommon as many faculty members across the United States had doubts about their schools keeping them safe on campus (Marek, 2020). Faculty members at Kennesaw State University (KSU) mentioned different reasons why they felt unsafe on campus, and most of them point to safety precautions not being enforced in the way that faculty members expected. In relation to faculty members' relationships with students and their overall classroom environment, while not all faculty members are content with their class modality, most of the faculty were able to transition to online classes smoothly. Faculty members were probably more receptive to teaching online classes because it was a commonly used countermeasure in preventing outbreaks on campus (Vaghela, 2020). Changing class modality to online instead of face-to-face more than likely also brought solace to those faculty members who felt they would be unsafe on campus.

\section{CONCLUSIONS}

The coronavirus (COVID-19) pandemic required institutions such as Kennesaw State University (KSU) to drastically change the way they operate on campus as well as to change the way their classes are delivered. This descriptive article used a survey to explore how faculty at KSU responded to these changes and to get their thoughts on their new environment. 
While most faculty tried their best to adjust to fully online classes and the new safety protocols on campus, they were not able to connect with students as they usually would - not only because of the online class modality but also out of fear of catching COVID-19 on campus. This was indeed a concern among many faculty members in colleges across the U.S. (Marek, 2020). KSU faculty's feelings of safety on campus were overall positive, but there were some faculty members who were unsure of whether they felt Kennesaw State University did an adequate job of cleaning/disinfecting certain areas and providing cleaning supplies to students and other faculty members. Overall, this study showed that faculty members are concerned about their students' learning environment as well as everyone's overall safety. Faculty are aware that KSU is trying to keep staff and students safe but feel there is a need for more instruction about safety guidelines as well as implementation of the guidelines.

While many institutions have tried to keep up with the guidelines provided by the CDC, there has been a learning curve (How colleges react to coronavirus outbreaks on campuses, 2020). Kennesaw State University followed all the safety protocols from the USG and the CDC to the best of their ability and will continue to do so. Faculty and students alike tried their best to keep up with the many changes that came with the new school year. The Fall 2020 semester served as a good trial run as changes are always being made to improve the quality of education at Kennesaw State University while still maintaining the safety guidelines to stop the spread of COVID-19.

\section{RESEARCH LIMITATIONS}

One of the major limitations of the study is that this study only looks at faculty members from only one major research university - Kennesaw State University. Another limitation is that demographic data was not collected, which means that how well our findings reflect the general consensus among different age groups, ethnicities, experience levels, occupation, and so on is difficult to ascertain. Another limitation is that the survey was only open to faculty members for ten days. For the next study, researchers should allow faculty members at least 30 days to fill out the survey as well as include demographic data questions to determine how well the survey results reflect the KSU faculty population.

\section{REFERENCES}

Alexander, B. (2020). How the coronavirus will change faculty life forever. Chronicle of Higher Education, 66(29).

Aufderheide, D., \& Gondles, E. (2020). The psychology of COVID-19. Corrections Today, pp. 8-13. Retrieved May/June 2020.

Auon, J.E. (2020, August 18). Why college campuses can't wait. The Washington Post. Retrieved from wapo.28810dd0-e17d-11ea-8181-606e603bb1c4

Borowiak, M., Ning, F., Pei, J., Zhao, S., Tung, H-R., \& Durett, R. (2020). Controlling the spread of COVID-19 on college campuses. Retrieved from arXiv.2008.07293v1

Camera, L. (2020, August 19). Universities wave the white flag in the face of campus coronavirus outbreaks. U.S. News \& World Report.

Center for Disease Control and Prevention. (2019). Coronavirus disease 2019 (COVID-19). Retrieved from cdc.gov/coronavirus/2019-ncov/prevent-getting-sick/prevention.html

Corbet, S., \& Siegel, T. (2020, September 18). Virus clusters at French universities give Europe a lesson. The Canadian Press.

Court, E., \& Lorin, J. (2020, August 19). Colleges embrace Covid testing as key for safe returns to campus. Retrieved August 2020, from Bloomberg.com

Diep, F. (2020). How do you quarantine for coronavirus on a college campus? Chronicle of Higher Education, 66(25).

Dixon, J.A. (2020). Campus concerns. Library Journal, pp. 18-19.

Gould, K.J. (2020, May). COVID-19 and college students with special needs. EP Magazine, pp. 44-46. 
Grayer, A., \& Stuart, E. (2020). Hundreds of Covid-19 cases reported as students return to college campuses. CNN Wire.

Justis, N., Litts, B.K., Reina, L., \& Rhodes, L. (2020). Cultivating staff culture online: How Edith Bowen Laboratory School responded to COVID-19. Information and Learning Sciences, 121(5/6), 453460. https://doi.org/10.1108/ILS-04-2020-0136

Kennedy, M. (2020). Classes dismissed. American School \& University, pp. 14-17.

Khan, A.M., Patra, S., Vaney, N., Mehndiratta, M., \& Chauhan, R. (2021). Rapid transition to online practical classes in preclinical subjects during COVID-19: Experience from a medical college in North India. Medical Journal Armed Forces India, 77, S161-S167.

König, J., Jager-Biela, D.J., \& Glutsch, N. (2020). Adapting to online teaching during COVID-19 school closure: Teacher education and teacher competence effects among early career teachers in Germany. European Journal of Teacher Education, 43(4), 608-622.

Marek, L. (2020). Campus is calling, despite the dangers: Amid lingering COVID worries, universities plan to bring back students - and reluctant faculty. Crain's Chicago Business, 43(28).

Mouchantaf, M. (2020). The COVID-19 pandemic: Challenges faced and lessons learned regarding distance learning in Lebanese higher education institutions. Theory and Practice in Language Studies, 10(10), 1259. https://doi.org/10.17507/tpls.1010.11

Nadworny, E., \& Inskeep, S. (2020, September 9). Despite mass testing, University of Illinois sees coronavirus cases rise. Retrieved September 2020, from NPR (Morning Edition).

Nocera, J. (2020, May 25). The myth of the empty campus. Bloomberg BusinessWeek.

NPR (All Things Considered). (2020). College athletes return to campus for voluntary training despite safety concerns. Retrieved June 2020, from https://link.gale.com/apps/doc/A626081691/LitRC? $\mathrm{u}=\mathrm{kennesaw} \_\mathrm{main} \& \mathrm{sid}=\mathrm{LitRC} \& \mathrm{xid}=94 \mathrm{~d} 68 \mathrm{cc} 0$

NPR (All Things Considered). (2020). How colleges react to coronavirus outbreaks on campuses. Retrieved September 2020, from https://link.gale.com/apps/doc/A734720980/LitRC?u=kennesaw _main\&sid=LitRC\&xid $=$ d958216d

NPR (Weekend Edition Sunday). (2020, August 23). College road trip: UNC students move out after COVID-19 outbreak. Retrieved from https://link.gale.com/apps/doc/A633424533.LitRC?u= kennesaw_main\&sid=LitRC\&xid=a37adalc

PR Newswire. (2020). 1,000+ Colleges and universities sign-up for \#CampusClear, a free self-screening mobile app built by Ivy.ai.

Raimonde, O. (2020, August 30). Colleges with Covid outbreaks advised to keep students on campus. Retrieved from Bloomberg.com

Reilly, K. (2020, July 15). Coronavirus outbreaks linked to fraternity houses are a warning for college campuses. Retrieved from Time.com

Roetert, E.P., Bell, L., \& Hainline, B. (2020). COVID-19 and its impact on players' mental health. ITF Coaching and Sport Science Review, 81(28), 19-21.

Shuja, K.H., Aqeel, M., Jaffar, A., \& Ahmed, A. (2020). COVID-19 pandemic and impending global mental health implications. Psychiatria Danubina, 32(1), 32-35.

Vaghela, V. (2020). Cambridge University moves all lectures online until 2021. Retrieved May 2020, from Bloomberg.com

Weissman, S. (2020). Safe space. Diverse: Issues in Higher Education, pp. 18-19. Retrieved June 2020.

WHO. (2020, March 11). WHO director-general's opening remarks at the media briefing on COVID-1911 March 2020. Retrieved from who.int/dg/speeches/detail/who-director-general-s-openingremarks-at-the-media-briefing-on-covid-19---11 march-2020

Wood, S. (2020). Finding an ally. Diverse: Issues in Higher Education, pp. 22-23. Retrieved June 2020. 


\section{APPENDIX A: SURVEY QUESTIONS}

\section{TABLE 1 \\ LIKERT-SCALE SURVEY QUESTIONS}

\begin{tabular}{|l|l|}
\hline \multicolumn{1}{|l|}{ \# } & \multicolumn{1}{c|}{ Questions } \\
\hline 1 & Do you feel safe coming to work at KSU? \\
\hline 2 & Has COVID-19 impacted the way you do work at KSU? \\
\hline 3 & Have you been provided with training regarding changes to your job due to COVID-19? \\
\hline 4 & Are you required to wear a mask during the course of your work? \\
\hline 5 & Have you heard of KSU's Presidential Task Force? \\
\hline 6 & Have you taken the COVID-19 Self-Assessment provided by KSU? \\
\hline 7 & Have you taken advantage of the on-campus COVID-19 testing? \\
\hline 8 & Did you receive a branded KSU face covering? \\
\hline 9 & $\begin{array}{l}\text { Do you feel that KSU has taken the appropriate steps to ensure multiple cleanings of high-traffic } \\
\text { areas? }\end{array}$ \\
\hline 10 & Do you feel safe eating at Stingers? \\
\hline 11 & Do you feel safe using the Wellness Center? \\
\hline 12 & Regarding Social Distancing Guidelines, do you know what "rules of the road" means? \\
\hline 13 & Do you find it easy to stay 6 feet apart from everyone while indoors? \\
\hline 14 & $\begin{array}{l}\text { Do you feel that the high-touch surfaces are being cleaned often enough to prevent COVID- } \\
\text { 19 from spreading? }\end{array}$ \\
\hline 15 & Have you seen people indoors who are not wearing a face covering when they should? \\
\hline $15 a$ & Are you likely to approach that person and correct their behavior? \\
\hline 16 & Do you feel safe using the Owl Bus? \\
\hline 17 & Do you feel that the Owl Bus is being cleaned often enough to prevent COVID-19 from spreading? \\
\hline
\end{tabular}

TABLE 2

FREE RESPONSE SURVEY QUESTIONS

\begin{tabular}{|r|l|}
\hline$\#$ & Questions \\
\hline 1 & Has anything changed about your office hours? \\
\hline 2 & Is interacting with students more of a challenge now? If yes, how so? \\
\hline 3 & What kind of format is your class being delivered? What kind of format was it supposed to be? \\
\hline 4 & What changes to your class content/schedule did you have to make to accommodate your new \\
\hline 5 & format? \\
\hline 6 & What changes have impacted you the most due to COVID-19? \\
\hline 7 & Are cleaning supplies available in every classroom? If yes, are students using them? \\
\hline 8 & Have you been provided with cleaning supplies? \\
\hline
\end{tabular}


APPENDIX B: SURVEY RESPONSES AND DESCRIPTIVE STATISTICS

TABLE 3

RESPONSES TO RESEARCH QUESTION \#1: WERE FACULTY MEMBERS ABLE TO IMPLEMENT THE SAFETY GUIDELINES PUT IN PLACE BY KENNESAW STATE UNIVERSITY?

\begin{tabular}{|c|c|c|c|c|c|c|c|}
\hline $\begin{array}{l}\text { Question } \\
\text { Number }\end{array}$ & Question & $\begin{array}{c}\text { Strongly } \\
\text { Agree }\end{array}$ & $\begin{array}{c}\text { Somewhat } \\
\text { Agree }\end{array}$ & Neither & $\begin{array}{l}\text { Somewhat } \\
\text { Disagree }\end{array}$ & Disagree & $\begin{array}{l}\text { Strongly } \\
\text { Disagree }\end{array}$ \\
\hline 3 & $\begin{array}{l}\text { Have you been } \\
\text { provided with } \\
\text { training regarding } \\
\text { changes to your } \\
\text { job due to } \\
\text { COVID-19? }\end{array}$ & 17 & 12 & 8 & 6 & 3 & 2 \\
\hline 4 & $\begin{array}{l}\text { Are you required } \\
\text { to wear a mask } \\
\text { during the course } \\
\text { of your work? }\end{array}$ & 29 & 11 & 3 & 1 & 1 & 3 \\
\hline 5 & $\begin{array}{l}\text { Have you heard of } \\
\text { KSU's } \\
\text { Presidential Task } \\
\text { Force? }\end{array}$ & 30 & 11 & 4 & 1 & 1 & 1 \\
\hline 6 & $\begin{array}{l}\text { Have you taken } \\
\text { the COVID-19 } \\
\text { Self-Assessment } \\
\text { provided by } \\
\text { KSU? }\end{array}$ & 14 & 4 & 3 & 1 & 11 & 15 \\
\hline 7 & $\begin{array}{l}\text { Have you taken } \\
\text { advantage of the } \\
\text { on-campus } \\
\text { COVID-19 } \\
\text { testing? }\end{array}$ & 5 & 1 & 5 & 0 & 12 & 23 \\
\hline 8 & $\begin{array}{l}\text { Did you receive a } \\
\text { branded KSU face } \\
\text { covering? }\end{array}$ & 39 & 4 & 0 & 1 & 1 & 2 \\
\hline 9 & $\begin{array}{l}\text { Do you feel that } \\
\text { KSU has taken } \\
\text { the appropriate } \\
\text { steps to ensure } \\
\text { multiple cleanings } \\
\text { of high-traffic } \\
\text { areas? }\end{array}$ & 19 & 14 & 6 & 4 & 2 & 2 \\
\hline
\end{tabular}




\begin{tabular}{|c|l|l|l|l|l|l|l|}
\hline 12 & $\begin{array}{l}\text { Regarding Social } \\
\text { Distancing } \\
\text { Guidelines, do } \\
\text { you know what } \\
\text { "rules of the road" } \\
\text { means? }\end{array}$ & 21 & 9 & 0 & 1 & 6 & 11 \\
\hline
\end{tabular}

TABLE 4

DESCRIPTIVE STATISTICS FOR RESEARCH QUESTION \#1: WERE FACULTY MEMBERS ABLE TO IMPLEMENT THE SAFETY GUIDELINES PUT IN PLACE BY KENNESAW STATE UNIVERSITY?

\begin{tabular}{|c|c|c|c|c|c|c|c|}
\hline $\begin{array}{l}\text { Question } \\
\text { Number }\end{array}$ & Question & Minimum & Maximum & Mean & $\begin{array}{c}\text { Std } \\
\text { Deviation }\end{array}$ & Variance & Count \\
\hline 3 & $\begin{array}{l}\text { Have you been } \\
\text { provided with } \\
\text { training } \\
\text { regarding } \\
\text { changes to your } \\
\text { job due to } \\
\text { COVID- } \\
19 ?\end{array}$ & 1.00 & 6.00 & 2.42 & 1.44 & 2.08 & 48 \\
\hline 4 & $\begin{array}{l}\text { Are you } \\
\text { required to wear } \\
\text { a mask during } \\
\text { the course of } \\
\text { your work? }\end{array}$ & 1.00 & 6.00 & 1.81 & 1.38 & 1.90 & 48 \\
\hline 5 & $\begin{array}{l}\text { Have you heard } \\
\text { of KSU's } \\
\text { Presidential Task } \\
\text { Force? }\end{array}$ & 1.00 & 6.00 & 1.65 & 1.09 & 1.19 & 48 \\
\hline 6 & $\begin{array}{l}\text { Have you } \\
\text { taken the } \\
\text { COVID-19 } \\
\text { Self- } \\
\text { Assessment } \\
\text { provided by } \\
\text { KSU? }\end{array}$ & 1.00 & 6.00 & 3.75 & 2.11 & 4.44 & 48 \\
\hline 7 & $\begin{array}{l}\text { Have you taken } \\
\text { advantage of } \\
\text { the on-campus } \\
\text { COVID-19 } \\
\text { testing? }\end{array}$ & 1.00 & 6.00 & 4.78 & 1.68 & 2.82 & 46 \\
\hline 8 & $\begin{array}{l}\text { Did you receive a } \\
\text { branded KSU } \\
\text { face covering? }\end{array}$ & 1.00 & 6.00 & 1.45 & 1.22 & 1.48 & 47 \\
\hline
\end{tabular}




\begin{tabular}{|c|l|l|l|l|l|l|}
\hline 9 & $\begin{array}{l}\text { Do you feel } \\
\text { that KSU has } \\
\text { taken the } \\
\text { appropriate } \\
\text { steps to ensure } \\
\text { multiple } \\
\text { cleanings of } \\
\text { high-traffic } \\
\text { areas? } \\
\text { Regarding Social } \\
\text { Distancing } \\
\text { Guidelines, do } \\
\text { you know what } \\
\text { "rules of the } \\
\text { road" means? }\end{array}$ & 1.00 & 6.00 & 2.19 & 1.38 & 1.90 \\
\hline
\end{tabular}

TABLE 5

RESPONSES TO RESEARCH QUESTION \#2: HOW DID FACULTY MEMBERS RESPOND TO THEIR NEW ENVIRONMENT?

\begin{tabular}{|c|c|c|c|c|c|c|c|}
\hline $\begin{array}{l}\text { Question } \\
\text { Number }\end{array}$ & Questions & $\begin{array}{c}\text { Strongly } \\
\text { Agree }\end{array}$ & $\begin{array}{l}\text { Somewhat } \\
\text { Agree }\end{array}$ & Neither & $\begin{array}{l}\text { Somewhat } \\
\text { Disagree }\end{array}$ & Disagree & $\begin{array}{l}\text { Strongly } \\
\text { Disagree }\end{array}$ \\
\hline 1 & $\begin{array}{l}\text { Do you feel safe } \\
\text { coming to work } \\
\text { at KSU? }\end{array}$ & 19 & 15 & 1 & 5 & 6 & 2 \\
\hline 10 & $\begin{array}{l}\text { Do you feel safe } \\
\text { eating at } \\
\text { Stingers? }\end{array}$ & 9 & 4 & 18 & 0 & 7 & 10 \\
\hline 11 & $\begin{array}{l}\text { Do you feel safe } \\
\text { using the } \\
\text { Wellness } \\
\text { Center? }\end{array}$ & 6 & 2 & 21 & 3 & 4 & 11 \\
\hline 13 & $\begin{array}{l}\text { Do you find it easy } \\
\text { to stay } 6 \text { feet apart } \\
\text { from everyone } \\
\text { while indoors? }\end{array}$ & 13 & 15 & 2 & 5 & 4 & 9 \\
\hline 14 & $\begin{array}{l}\text { Do you feel that } \\
\text { the high-touch } \\
\text { surfaces are being } \\
\text { cleaned often } \\
\text { enough to prevent } \\
\text { COVID-19 from } \\
\text { spreading? }\end{array}$ & 14 & 10 & 8 & 8 & 5 & 3 \\
\hline
\end{tabular}




\begin{tabular}{|c|l|l|l|l|l|l|l|}
\hline 15 & $\begin{array}{l}\text { Have you seen } \\
\text { people indoors who } \\
\text { are not wearing a } \\
\text { face covering when } \\
\text { they should? }\end{array}$ & 15 & 11 & 5 & 2 & 3 & 11 \\
\hline $15 \mathrm{a}$ & $\begin{array}{l}\text { Are you likely to } \\
\text { approach that } \\
\text { person and correct } \\
\text { their behavior? }\end{array}$ & 5 & 7 & 6 & 7 & 7 & 15 \\
\hline 16 & $\begin{array}{l}\text { Do you feel safe } \\
\text { using the Owl } \\
\text { Bus? }\end{array}$ & $\begin{array}{l}\text { Do you feel that the } \\
\text { Owl Bus is being } \\
\text { cleaned often } \\
\text { enough to prevent } \\
\text { COVID-19 from } \\
\text { spreading? }\end{array}$ & 1 & 2 & 38 & 0 & 3 \\
\hline
\end{tabular}

TABLE 6

DESCRIPTIVE STATISTICS FOR RESEARCH QUESTION \#2: HOW DID FACULTY MEMBERS RESPOND TO THEIR NEW ENVIRONMENT?

\begin{tabular}{|c|l|c|c|c|c|c|c|}
\hline $\begin{array}{c}\text { Question } \\
\text { Number }\end{array}$ & \multicolumn{1}{|c|}{ Questions } & Minimum & Maximum & Mean & $\begin{array}{c}\text { Std } \\
\text { Deviation }\end{array}$ & Variance & Count \\
\hline 1 & $\begin{array}{l}\text { Do you feel safe } \\
\text { coming to work } \\
\text { at KSU? }\end{array}$ & 1.00 & 6.00 & 2.38 & 1.58 & 2.48 & 48 \\
\hline 10 & $\begin{array}{l}\text { Do you feel safe } \\
\text { eating at Stingers? }\end{array}$ & 1.00 & 6.00 & 3.46 & 1.76 & 3.08 & 48 \\
\hline 11 & $\begin{array}{l}\text { Do you feel } \\
\text { safe using the } \\
\text { Wellness Center? }\end{array}$ & 1.00 & 6.00 & 3.64 & 1.63 & 2.66 & 47 \\
\hline 13 & $\begin{array}{l}\text { Do you find it } \\
\text { easy to stay 6 } \\
\text { feet apart from } \\
\text { everyone while } \\
\text { indoors? }\end{array}$ & 1.00 & 6.00 & 2.98 & 1.88 & 3.52 & 48 \\
\hline $\begin{array}{l}\text { Do you feel that } \\
\text { the high-touch } \\
\text { surfaces are } \\
\text { being cleaned } \\
\text { often enough to } \\
\text { prevent COVID- } \\
19 \text { from } \\
\text { spreading? }\end{array}$ & 1.00 & 6.00 & 2.77 & 1.57 & 2.47 & 48 \\
\hline
\end{tabular}




\begin{tabular}{|c|l|l|l|l|l|l|l|}
\hline 15 & $\begin{array}{l}\text { Have you } \\
\text { seen people } \\
\text { indoors who } \\
\text { are not } \\
\text { wearing a face } \\
\text { lovering } \\
\text { when } \\
\text { they should? }\end{array}$ & 1.00 & 6.00 & 3.00 & 1.98 & 3.91 & 47 \\
\hline $15 \mathrm{a}$ & $\begin{array}{l}\text { Are you likely to } \\
\text { approach that } \\
\text { person and } \\
\text { correct their } \\
\text { behavior? }\end{array}$ & 1.00 & 6.00 & 4.04 & 1.76 & 3.10 & 47 \\
\hline 16 & $\begin{array}{l}\text { Do you feel safe } \\
\text { using the Owl } \\
\text { Bus? }\end{array}$ & 1.00 & 6.00 & 3.52 & 1.38 & 1.92 & 48 \\
\hline 17 & $\begin{array}{l}\text { Do you feel that } \\
\text { the Owl Bus is } \\
\text { being cleaned } \\
\text { often enough to } \\
\text { prevent COVID- } \\
19 \text { from } \\
\text { spreading? }\end{array}$ & 1.00 & 6.00 & 3.17 & 0.87 & 0.75 & 46 \\
\hline
\end{tabular}

TABLE 7

RESPONSES TO RESEARCH QUESTION \#3:

HOW DID THE CHANGES TO THE SCHOOL ENVIRONMENT IMPACT FACULTY MEMBERS' CLASSROOM MODALITIES AND THEIR RELATIONSHIPS WITH STUDENTS?

\begin{tabular}{|c|l|c|c|c|c|c|c|}
\hline $\begin{array}{c}\text { Question } \\
\text { Number }\end{array}$ & \multicolumn{1}{|c|}{ Question } & $\begin{array}{c}\text { Strongly } \\
\text { Agree }\end{array}$ & $\begin{array}{c}\text { Somewhat } \\
\text { Agree }\end{array}$ & Neither & $\begin{array}{c}\text { Somewhat } \\
\text { Disagree }\end{array}$ & Disagree & $\begin{array}{c}\text { Strongly } \\
\text { Disagree }\end{array}$ \\
\hline 2 & $\begin{array}{l}\text { Has COVID-19 } \\
\text { impacted the way } \\
\text { you do work at } \\
\text { KSU? }\end{array}$ & 32 & 11 & 0 & 0 & 1 & 4 \\
\hline
\end{tabular}

TABLE 8

DESCRIPTIVE STATISTICS FOR RESEARCH QUESTION \#3:

HOW DID THE CHANGES TO THE SCHOOL ENVIRONMENT IMPACT FACULTY MEMBERS' CLASSROOM MODALITIES AND THEIR RELATIONSHIPS WITH STUDENTS?

\begin{tabular}{|c|l|c|c|c|c|c|c|}
\hline $\begin{array}{c}\text { Question } \\
\text { Number }\end{array}$ & \multicolumn{1}{|c|}{ Question } & Minimum & Maximum & Mean & $\begin{array}{c}\text { Std } \\
\text { Deviation }\end{array}$ & Variance & Count \\
\hline 2 & $\begin{array}{l}\text { Has COVID-19 } \\
\text { impacted the } \\
\text { way you do } \\
\text { work at KSU? }\end{array}$ & 1.00 & 6.00 & 1.73 & 1.45 & 2.11 & 48 \\
\hline
\end{tabular}

